\title{
TECHNICAL AND VOCATIONAL EDUCATION AND TRAINING SKILLS: AN ANTIDOTE FOR JOB CREATION
AND SUSTAINABLE DEVELOPMENT OF
NIGERIAN ECONOMY AN ANTIDOTE FOR JOB CREATION
AND SUSTAINABLE DEVELOPMENT OF
NIGERIAN ECONOMY AN ANTIDOTE FOR JOB CREATION
AND SUSTAINABLE DEVELOPMENT OF
NIGERIAN ECONOMY
}

James Edomwonyi Edokpolor

Benson Idahosa University, Nigeria

E-mail: jedokpolor@biu.edu.ng

Robinson Osarumwense Owenvbiugie

University of Benin, Nigeria

E-mail: Osarumwense.owenvbiugie@uniben.edu

\begin{abstract}
The research is aimed at assessing the important role of TVET on job creation and sustainable development of Nigerian economy. Two research questions were answered using mean and standard deviation statistics, while two hypotheses were tested using t-test statistic. A survey method was employed for the research. A four-point scale questionnaire was employed as the instrument for collection of data. The population consists of 332 TVET lecturers in 3 universities and 4 colleges of education in Edo and Delta States. There was no need to adopt sampling technique, nor select any sample size, since the entire population is of a manageable size. The instrument was validated by two experts and its reliability coefficient value using Cronbach alpha method was 0.81 . The research revealed that TVET can equip students with skills for job creation and sustainable development of Nigerian economy. It also revealed that there was no significant difference between the mean ratings of TVET lecturers in Edo and Delta States on the extent to which TVET can equip students with skills for job creation. It further revealed that there was no significant difference between the mean ratings of male and female TVET lecturers on the extent to which TVET can equip students with skills for sustainable development of Nigerian economy. Optimizing sufficient amount of financial resources, regular supplies of state-of-the-art facilities, sourcing for qualified manpower, and organization of advocacy programme, that would help in effective management delivery of TVET were further recommended.
\end{abstract}

Keywords: job creation, Nigerian economy, sustainable development, social ills, TVET skills.

\section{Introduction}

A number of developing nations across the globe have taken the lead to invest sufficient amount of resources (both financially and otherwise) for the development of their education sector. This effort has consequently improved the quality of their education and the lives of their youths. The productive capabilities of these youths in terms of skills and competencies have been the key driver of transformation from stagnation to growth and from low-income status to high-income status as well as overcoming the problems of unemployment and underdevelopment. This means that skilled and competent manpower played a key role in their development processes. Economic development therefore depends on effective use of intangible assets, such as skills and/or competencies as a resource for achieving competitive advantage 
James Edomwonyi EDOKPOLOR, Robinson Osarumwense OWENVBIUGIE. Technical and vocational education and training skills: An antidote for job creation and sustainable development of Nigerian economy

\section{PROBLEMS \\ OF EDUCATION \\ IN THE $21^{\text {st }}$ CENTURY Vol. 75, No. 6, 2017 \\ 536}

(Lisbon Council, 2007). A skill can be defined as the ability to perform tasks and solve problems (Organization for Economic Co-operation and Development, 2009). For instance, the term ' $21^{\text {st }}$ century skills' is often used to refer to sets of cognitive, non-cognitive, and technical skills (Global e-Schools and Communities Initiative, 2013). Cognitive skills are basic abilities that people use to think, study, and learn, for example, literacy, numeracy, and the use of theory, concepts, or tacit knowledge, non-cognitive skills refer to socio-emotional personality traits, behaviours, and attitudes (also called 'soft' skills), while technical skills include business, ICT, and specialized skills (Burton, cited in GeSCI, 2013). Technical skills are also regarded as industry-specific skills required for the production of goods and services (Edwards, 2008; Prospects, 2010). In view of this, it is clear that individuals can create their own jobs or become self-employed by equipping them with these skills which can be acquired through technical and vocational education and training (TVET).

Technical and Vocational Education and Training is an integral part of secondary and post-secondary education that is designed to educate individuals about, through and for careers (Rojewski., Asunda, \& Kim, 2008). It is aimed at developing human resources and facilitates the transition of a nation to a more sustainable economy. Broadly speaking, the National Association of State Directors of Career Technical Education Consortium (NASDCTEC) acknowledged that:

TVET provides students and adults with the technical skills, knowledge and training necessary to succeed in specific occupations and careers. It also prepares students for the world of work by introducing them to workplace competencies that are essential no matter what career they choose. And, TVET takes academic content and makes it accessible to students by providing it in a hands-on context (NASDCTEC, 2003).

In fact, advanced science and technology education and training have been and will continue to be the engine for economic growth and national security ( $\mathrm{Li}$, Swaminathan \& Tang, 2009). As pointed out in the Federal Republic of Nigeria (FRN) science and technology policy document:

Science and technology are to modern life what the hands are to the body. They are used to harness the forces of nature and to transform the raw resources with which nature endows man into goods and services for better quality of life (FRN, 1986).

The United Nation's International Center for TVET (UNEVOC) in its desire to highlight the important role of TVET in relation to job creation and sustainable development, ascertained that:

The changing nature of the world of work, especially due to globalization and technological change, demands that TVET develop a skilled, committed and motivated workforce that understands how global changes impact upon local opportunities for business and industry and how these changes impact upon the quality of social, economic and environmental conditions (UNESCO-UNEVOC, 2009).

The UNESCO-UNEVOC (2012) noted in its report on the important role of TVET that: This form of education has great prospect for tackling poverty, enhancing employability through skill acquisition and boosting sustainable development in different continents. Many people, both in developed and developing countries, recognized the important role that TVET plays in equipping individuals with requisite skills, thus enabling them to effectively participate in social, economic and technology innovation processes (Netherlands Organization for International Cooperation in Higher Education, 2010). The UNESCO (2010) further estimated that about $80 \%$ of occupations around the world are based on the application of TVET skills for the world of work. This implies that the future success of any country, individual, enterprise, and community increasingly depend on the possession of TVET skills. No wonder, Akerele (2007) 
and Rufai (2013) pointed out that TVET is a viable aspect of education that exposes students for the acquisition of demonstrable skills that could further be transferred into the economic benefit as well as sustainable livelihood.

In the framework of "what is TVET?" the UNESCO-UNEVOC indicated that TVET is concerned with the acquisition of knowledge and skills for the world of work (UNESCO, 2010). It is seen as a special type of programme that emphasized the application of knowledge, skills and attitudes required for employment in a particular occupation or cluster of related occupations in any field of social and economic activity (Gu, Gomes \& Brizuela, 2011). Similarly, MacLean and David (2009) asserted that TVET is concerned with the acquisition of knowledge and skills for the world of work to increase the opportunities for productive empowerment and economic development in knowledge economies and rapidly changing work environment. MacLean and Wilson (2009) sees it as acquirement of education and skillfulness for the world of work to raise prospects for productive work and personal empowerment and socio-economic development for sustainable livelihood in the speedily changing work milieu. Furthermore, Kingombe (2012) and Badawi (2013) stipulated that TVET was adopted by the UNESCO and the ILO in consultation with their member States and partner agencies to mean those facets of educational and training procedures involving the study of technologies and related sciences, and the acquisition of practical skills, attitudes, understanding and knowledge in various sectors of economic and social life. The UNESCO (2005) also posited that the aspect that differentiates TVET from other forms of education and training are its emphasis on work productivity. No wonder, Awotunde (2000) and Igwe and Oragwu (2014) pointed out that TVET is an integral part of national development strategies in many societies because of its impact on productivity and economic development.

The Federal Republic of Nigeria (FRN) (2004) in her education policy document captures the aims of TVET to its recipients as manpower development strategy that leads to the acquisition of practical and applied skills as well as basic scientific knowledge for useful living within the society. Typically, the purpose of TVET is understood as both improving social and economic well-being of individuals as well as serving society by ensuring an educated workforce (Adams \& Gamage, 2008). To keep fulfilling this dual purpose, leaders and managers of TVET need to keep optimizing sufficient amount of resources (both financially and otherwise) to meet the needs of students and the society. The present research focuses on the important role of TVET in developing requisite skills for job creation and sustainable development of Nigerian economy.

It can be deduced from the foregoing that TVET is an important programme that equips recipients with the requisite skills required to improve access to employment opportunities, raise income capacities for poverty alleviation, and promote peace and security. Hailu (2012) asserted that after or having acquired the necessary skills, TVET graduates' career options are either wage employment or self-employment, in which both are vital that the former is to supply the industry with the skilled labour and the latter is job creation. Drawing from the international experience, especially in some countries, like Japan, Korea, Singapore, and other Asian industrializing tigers, the Nigerian government recently established a number of TVET institutions so as to launch the country steadily on the path of industrialization and economic development in furtherance of her commitment to TVET sector. Despite the effort to tackle the issue of unemployment and scourge of poverty by different approaches, the goal of abundant wealth creation and youth employment still remains elusive (Olaitan, 1996; Adekoya, 2010). The quest for technological breakthroughs, industrialization and economic development is slow and unimpressive as evidenced by the increasing rates of unemployment and poverty (Ladipo, Akhuemonkhan \& Raimi, 2013).

The quest to promote technological progress, industrialization and national development is far from being actualized, probably because TVET programme is currently constrained by so 
James Edomwonyi EDOKPOLOR, Robinson Osarumwense OWENVBIUGIE. Technical and vocational education and training skills: An antidote for job creation and sustainable development of Nigerian economy

OF EDUC

IN THE $21^{\text {st }}$ CENTURY Vol. 75, No. 6, 2017

538

many challenges. Prominent among them are inadequate infrastructure and facilities, dearth of qualified staff with practical experience relevant for training students to meet the contemporary needs of industry and employers of labour, wide gap between TVET and industry, weak support by industries to TVET institutions, inadequate budgetary allocations for TVET, absence of a National Qualifications framework and inadequate regulatory and monitoring activities, among others (Chukumerije, 2011). This situation also affects other developing nations especially in the South Asian region like Pakistan, Afghanistan, Bangladesh, India, among others because their TVET system has been characterized by low level of competent teachers, limited private sector involvement, and inadequate budgetary allocations (H1-Haq \& Haq, cited in Agrawal, 2013). In other words, TVET in South Asian region is neither supporting a high economic growth rate, nor expanding the global markets, nor increasing employment opportunities. This is because, many youths in these countries are unable to find jobs, while those who are already working are not gainfully employed; in other words they are under-employed (Ekpenyong \& Edokpolor, 2015a).

The paradigm of the world today appears to be shifting to that of TVET as evidenced by some Asian countries. In Japan, Singapore and Korea, for instance, TVET sector has contributed significantly in the process of economic development (Asian Development Bank, 2004). In these countries, TVET system is well-established because the rate of unemployment has remained constantly low, both because their populations possessed TVET skills and the high economic growth rate that the skilled populations are fostering (H1-Haq \& Haq, cited in Agrawal, 2013). Based on this success story, Nigerian government may have to look the policies that have been put in place in these Asian countries so as to enable her youths to acquire marketable skills and translate these skills into job creating ventures. In this sense, job creation can be seen as a means of using individuals' acquired skills to achieve self-reliance in order to ensure economic survival. Job creation and unemployment may be likened to two sides of a coin and are parallel in nature. Job creation is positive, while unemployment is negative to the sustainable economic development.

The debate at the national assembly over the budget may have shown that Nigeria appreciates the gravity of mass unemployment and underemployment in the face of the pressing needs of 191.8 million people as estimated by the United Nations (Worldometers, 2017). It is disheartening to see that Nigeria is under-developing and not moving forward in a land that is once considered to be flowing with milk and honey. Programmes embarked upon by the government, aimed at giving the majority of youth economic lifeline, end up empowering the few, which in turn leaves the larger number unemployed, which eventually create a social burden and all manner of social ills (Adeyemi \& Titiloye, 2014). For instance, the rate of unemployment has increased from $13.3 \%$ in second quarter of 2016 to $13.9 \%$ in third quarter of 2016 , while the rate of underemployment has increased from $19.3 \%$ in second quarter of 2015 to $19.7 \%$ in third quarter of 2016 (National Bureau of Statistics, 2016). This unpleasant situation has consequently created the scarcity of basic needs among the populace (Igbinedion, Edokpolor \& Oyenuga, 2015). Unemployment and poverty have in some cases led to fall in national output, high level dependence ratio, and low standard of living, to an extent that a great multitude of people in Nigeria live in abject misery (Osinubi, 2005). These twin socio-economic problems have led to the tremendous increase in criminal activities and social vices in Nigeria (Ekpo, 2011; Olajide, 2015). Unemployment and poverty may also be seen as potential sources of political instability in Nigeria for disenchanted, disgruntled and revolutionary elements (Anyanwu \& Oaikhenan, cited in Olajide, 2015).

The increasing rate of unemployment is a mere pointer to the fact that most Nigerian youths may not have the skill to start and operate a business and become self-reliant. This means that the country at large suffers economically, lacking the skilled manpower for job creation and sustainable development. Unemployment is a major socio-economic problem that 
affects Nigerian economy. It has become a national crisis which has to be addressed if Nigeria is to enjoy sustainable development. It is evident that the high rate of unemployment is responsible for the under-developing Nigeria. Some of the youths who are unemployed have probably turned themselves to suicide bombers, vandals, terrorists, kidnappers, militants, armed robbers, and lots more, thereby causing Nigeria a great loss in revenue earnings, which in turn hinders her development. To keep meeting the requirement for skilled manpower and sustainable development of Nigerian economy, stakeholders of TVET programme need to keep optimizing sufficient amount of funds so that qualified staff, better facilities, and quality curriculum can be made available, which would further help in meeting the needs of students and the society. Tilak (2002) had remarked that TVET has an important role to play in alleviating mass unemployment, providing specific skills for self-employment and re-orienting student's attitudes towards societal growth. Maclean (2008) further stated that an effective skill development for employability and sustainable livelihood is essential if sustainable development is to be achieved, and this further provides a foundation for peace building through poverty alleviation and rising levels of income.

The high rate of unemployment and all manner of social ills in Nigeria has necessitated the need for governments, NGOs, parents and employers of labour to collaboratively invest their resources on TVET programme. This strategic management approach as pointed out by Adewuyi and Okemakinde (2013) can help to serve various purposes, which includes financial management, staff development, curriculum development, service delivery, students mentoring, equipment donation, raising course awareness, facility management, and lots more. The research of Burchardt, Le Grand and Piachaud (2002) also showed that investment in human capital (vocational knowledge and technical skills) stimulates economic growth and development by improving the quality of skilled manpower and it also saves social costs. This effort would further help to promote the development of knowledge and skills in home economics, business or office, agricultural science, as well as industrial technical, including a good blend of career guidance, entrepreneurship, and Information and Communication Technology (ICT) orientation. If these skills are well-taught and properly inculcated, they would help graduates of TVET to secure gainful employment; start-up their own business, and become employers of labour; and pursue further education both at the graduate and post-graduate levels. Also, exploiting employment opportunities seem to provide the dispensable income that further fuels sustainable development.

TVET skills in the context of this study denote those practical and applied skills needed to transform Nigerian economy from low-income status to high-income status. TVET skills for sustainable development simply mean adopting a more holistic approach to TVET programme with the hope of creating a rebranded Nigeria for youths in this present and future generation. It is aimed at helping youths to continuously acquire TVET skills to make informed decisions for the benefit of themselves and others, now and in the future. Ideally, TVET skills for sustainable development are regarded as an approach that not only provides theoretical information to youths but also gives them practical tools which could be used to move Nigeria towards development. This has made the important role of TVET skills on sustainable development to become crucial and stressed by multinational organizations (OECD, 2009; ADB, 2008; ILO, 2008; World Bank, 2007; Department for International Development 2007; European Training Foundation, 2006a).

Sustainable development is defined as the development that meets the needs of present generation without compromising the ability of future generations to meet their own needs (World Commission on Environment and Development, 1987). It has been defined by Kurya and Hassan (2007) as a continuous and progressive increase and expansion of the volume of goods or services provided in a given economy with the improvement in social, economic, and political life of the present and future generation. Hardi (1997) pointed out that sustainable 
James Edomwonyi EDOKPOLOR, Robinson Osarumwense OWENVBIUGIE. Technical and vocational education and training skills: An antidote for job creation and sustainable development of Nigerian economy

\begin{abstract}
PROBLEMS
OF EDUCATION

IN THE $21^{\text {st }}$ CENTURY Vol. 75, No. 6,2017

540

development is not a fixed state of harmony; rather, it is an on-going process of evolution in which people take actions leading to the development that meets their current needs without compromising the ability of future generations to meet their own needs. With these conceptual understandings in place, sustainable development of Nigerian economy can be seen as a pattern of development that permits the future generations to have access to basic life-sustaining essentials, such as food, protection, healthcare, clothing and shelter as well as current generation having access to at least high level of living, self-esteem and freedom. Sen (1999) also argued that no one person is free if he or she cannot choose or is imprisoned by living on the margins of subsistence with no education and skill. It is on this premise that, Chukumerije (2011) stated that TVET remains the only imperative for economic development in Nigeria. The author however appraised different policies towards economic development but all to no avail. This research therefore sorts to assess the important role of TVET on job creation and sustainable development of Nigerian economy.
\end{abstract}

\section{Problem of the Research}

The increasing rates of unemployment and underemployment, together with the high incidence of economic degradation (or extreme underdevelopment) have necessitated the need to assess the important role of TVET programme on job creation and sustainable development of Nigerian economy. The National Bureau of Statistics (2016) had reported that unemployment rate has increased from about $13.3 \%$ in the second quarter of 2016 to about $13.9 \%$ in the third quarter of 2016, while underemployment rate has increased from about $19.3 \%$ in the second quarter of 2015 to about $19.7 \%$ in the third quarter of 2016 . The high rates of unemployment and underemployment appear to be responsible for the underdevelopment of Nigerian economy. As such, the insecurity in Nigeria such as the spate of suicide bombing, vandalism of oil facilities, armed robbery, terrorist attacks, kidnappings, assassination, militancy, breakdown of law and order are not unconnected with the increasing rates of unemployment, especially among youths (Ekpo, 2011; Olajide, 2015). Also, the existence of low levels of basic needs, self-esteem, and freedom appears to be connected with the high rates of unemployment and underemployment in the country. However, one of the ways to address these upsurges seems to lie in the acquisition of TVET skills. The acquisition of TVET skills may help in promoting entrepreneurial activities that would further provide the income capacity for economic growth and development in a sustainable manner. It is based on this situation that the authors embarked on this research in order to provide an empirical data on the important role of TVET in equipping recipient with requisite skills for job creation and sustainable development of Nigerian economy.

The main purpose of this research was to assess the extent to which TVET can equip students with the requisite skills for job creation and sustainable development of Nigerian economy. Specifically, the following research questions were put forward to guide the research:

1. To what extent can TVET equip students with skills for job creation?

2. To what extent can TVET equip students with skills for sustainable development?

\section{Methodology of the Research}

\section{General Characteristics}

The design employed for this study was a survey research design. Survey research design (also called descriptive research design) uses instruments such as questionnaires and interviews to gather information from groups of individuals (Ary, Jacobs, Sorensen, \& Walker, 
James Edomwonyi EDOKPOLOR, Robinson Osarumwense OWENVBIUGIE. Technical and vocational education and training skills: An antidote for job creation and sustainable development of Nigerian economy

2014). A survey design was suitable for this research, in that it allows the researchers to describe the opinions of technical and vocational education lecturers as regards the important role of TVET programme on job creation and sustainable development of Nigerian economy.

\section{Sample Selection}

The sample consists of 298 out of 332 technical and vocational education lecturers from universities and colleges of education in Edo and Delta States responded to the survey questionnaire, which yielded a return rate of $90 \%$. There was no need to adopt any sampling technique, nor select any sample size for the research study, because the population is of a manageable size (Jack \& Jelly, 2005).

\section{Instrument and Procedures}

A structured questionnaire was used as an instrument for data collection. The questionnaire was, titled: Questionnaire on the Extent to which TVET Can Equip Students with the Skills for Job Creation and Sustainable Development of Nigerian Economy (QETVETCESJCSDNE). Bryman (2007) stated that survey questionnaire is an appropriate instrument for collecting quantitative data. The instrument was validated by two experts. The reliability was determined by administering the instrument to 20 TVET lecturers who were not part of the research. Their responses were analyzed using the Cronbach alpha method, which yielded the coefficient alpha value of 0.81 . The questionnaire was further administered to the respondents by the researchers with the help of two trained research assistants. The questionnaire was retrieved as soon as they were completed.

\section{Data Analysis}

The data were analyzed using the mean, standard deviations and t-test statistics. The mean was used to answer the research questions, while the t-test was used to test the hypotheses at .05 level of significant. The standard deviations were used to determine the extent to which the responses of TVET lecturers were clustered to or deviated from the mean responses. The decision rule for the research questions was based on any calculate mean equal to, or greater than 2.50 means that technical and vocational education lecturers agreed to a very high extent with the questionnaire items raised; while any calculated mean less than 2.50 means that technical and vocational education lecturers disagreed to a very low extent with the questionnaire items raised. Also, any standard deviations value between 0.00 and 0.96 shows that technical and vocational education lecturer's responses are very close, which further means that their responses are clustered around the mean. Furthermore, the value (p) was used in taking the decisions on the hypotheses. If the p-value is less than or equal to 0.05 , the null hypotheses is rejected, but if the p-value is greater than 0.05 , the null hypotheses is not rejected. 
James Edomwonyi EDOKPOLOR, Robinson Osarumwense OWENVBIUGIE. Technical and vocational education and training skills: An antidote for job creation and sustainable development of Nigerian economy

OF EDU IN THE $21^{\text {st }}$ CENTURY Vol. 75, No. 6, 2017

\section{2}

\section{Results of the Research}

The results of the research are presented in Tables 1 and 2.

Table 1. Mean responses and standard deviations of vocational education lecturers in universities and colleges of education on the extent to which TVET can equip students with the skills to create jobs.

\begin{tabular}{|c|c|c|c|c|}
\hline S/N & $\begin{array}{l}\text { Item Statements } \\
\text { To what extent can TVET: }\end{array}$ & $\bar{x}$ & SD & Remarks \\
\hline 1. & Equip students with skills to set up documentary services (business centres). & 3.85 & .41 & $\mathrm{HE}$ \\
\hline 2. & Equip students with skills to manage documentary services (business centres). & 3.66 & .56 & $\mathrm{HE}$ \\
\hline 3. & $\begin{array}{l}\text { Equip students with skills to buy goods from production companies and sells in other } \\
\text { areas of demand. }\end{array}$ & 3.57 & .61 & $\mathrm{HE}$ \\
\hline 4. & Equip students with the skills to set up plumbing services. & 3.55 & .62 & $\mathrm{HE}$ \\
\hline 5. & Equip students with skills to set up electrical installation industry. & 3.47 & .62 & $\mathrm{HE}$ \\
\hline 6. & Equip students with skills to set up electrical electronics workshops. & 3.49 & .58 & $\mathrm{HE}$ \\
\hline 7. & Equip students with skills to set up automobile industry. & 3.48 & .58 & $\mathrm{HE}$ \\
\hline 8. & Equip students with skills to set up metal works industry. & 3.45 & .60 & $\mathrm{HE}$ \\
\hline 9. & Equip students with skills to set up welding and fabrication industry. & 3.43 & .62 & $\mathrm{HE}$ \\
\hline 10. & Equip students with skills set up block laying and concreting industry. & 3.40 & .61 & $\mathrm{HE}$ \\
\hline 11. & Equip students with skills to set up carpentry and wood work industry. & 3.47 & .58 & $\mathrm{HE}$ \\
\hline 12. & Equip students with skills to set up early child management services. & 3.32 & .59 & $\mathrm{HE}$ \\
\hline 13. & Equip students with skills to set up event management services. & 3.83 & .45 & $\mathrm{HE}$ \\
\hline 14. & Equip students with skills to set up fashion design industry. & 3.62 & .58 & $\mathrm{HE}$ \\
\hline 15. & Equip students with skills to set up cake baking industry. & 3.63 & .58 & HE \\
\hline 16. & Equip students with skills to set up catering services. & 3.61 & .59 & $\mathrm{HE}$ \\
\hline 17. & Equip students with skills to set up decoration services. & 3.43 & .61 & HE \\
\hline 18. & Equip students with skills to set up hospitality services. & 3.47 & .62 & $\mathrm{HE}$ \\
\hline 19. & Equip students with skills to set up textiles industry. & 3.48 & .56 & $\mathrm{HE}$ \\
\hline 20. & Equip students with skills to set up agro business firms. & 3.44 & .58 & $\mathrm{HE}$ \\
\hline 21. & Equip students with skills to set up soil laboratory services. & 3.42 & .60 & $\mathrm{HE}$ \\
\hline 22. & Equip students with skills to set up food laboratory services. & 3.44 & .63 & HE \\
\hline
\end{tabular}

Results of the data presented in Table 1 show the mean ratings of responses by vocational education lecturers in universities and colleges of education on the extent to which TVET programme can equip students with skills for job creation. The results revealed that 22 items had the mean scores that ranged from 3.32 to 3.85 , while the corresponding standard deviation values ranged from 0.41 to 0.63 . However, the mean scores are indications that TVET programmes to a very high extent can equip recipients with skills for entrepreneurial activities, while the 
James Edomwonyi EDOKPOLOR, Robinson Osarumwense OWENVBIUGIE. Technical and vocational education and training skills: An antidote for job creation and sustainable development of Nigerian economy

standard deviation values are indications that vocational education lecturer's responses are very

PROBLEMS

OF EDUCATION

IN THE $21^{\text {st }}$ CENTURY

Vol. 75, No. 6, 2017

close.

Table 2. Mean responses and standard deviations of vocational education lecturers in universities and colleges of education on the extent to which TVET can equip students with the skills to develop Nigerian economy in a sustainable manner.

\begin{tabular}{|c|c|c|c|c|}
\hline $\mathrm{S} / \mathrm{N}$ & $\begin{array}{l}\text { Item Statements } \\
\text { To what extent can TVET: }\end{array}$ & $\overline{\boldsymbol{x}}$ & SD & Remarks \\
\hline 23. & Equip students with skills to pursue lifelong learning activities. & 3.57 & .58 & $\mathrm{HE}$ \\
\hline 24. & Equip students with skills to participate entrepreneurial activities. & 3.49 & .63 & $\mathrm{HE}$ \\
\hline 25. & Equip students with skills to improve internal-generated revenue. & 3.51 & .59 & $\mathrm{HE}$ \\
\hline 26. & Equip students with skills to generate high income for youths. & 3.50 & .60 & $\mathrm{HE}$ \\
\hline 27. & Equip students with skills for poverty alleviation. & 3.49 & .60 & HE \\
\hline 28. & Equip students with skills to redeem youths from a bleak future & 3.46 & .60 & $\mathrm{HE}$ \\
\hline 29. & Equip students with attitudes to promote peace and security. & 3.48 & .61 & $\mathrm{HE}$ \\
\hline 30. & Equip students with skills to promote industrialization. & 3.40 & .62 & $\mathrm{HE}$ \\
\hline 31. & Equip students with skills to promote technological breakthroughs. & 3.47 & .58 & $\mathrm{HE}$ \\
\hline 32. & Equip students with skills to promote economic self-reliance. & 3.45 & .59 & $\mathrm{HE}$ \\
\hline 33. & Equip students with skills to provide basic needs among youths, & 3.44 & .62 & $\mathrm{HE}$ \\
\hline 34. & Equip students with skills to improve self-esteem among youths. & 3.47 & .63 & $\mathrm{HE}$ \\
\hline 35. & Equip students with skills to improve freedom among youths. & 3.45 & .62 & HE \\
\hline 36. & Equip students with skills to confidently invest on domestic and foreign trade. & 3.42 & .60 & $\mathrm{HE}$ \\
\hline
\end{tabular}

Results of the data presented in Table 2 show the mean ratings of responses by vocational education lecturers in universities and colleges of education on the extent to which TVET programmes can equip students with skills for sustainable development of Nigerian economy. The results revealed that 14 items had the mean scores that ranged from 3.42 to 3.57 , while the corresponding standard deviation values ranged from 0.58 to 0.63 . However, the mean scores are indications that TVET programmes to a very high extent can equip students with skills for sustainable development of Nigerian economy, while the standard deviation values are indications that vocational education lecturer's responses are very close.

Hypothesis 1: $\quad$ There is no significant difference between the mean responses of TVET lecturers in Edo and Delta States on the extent to which TVET can equip students with skills for job creation. 
James Edomwonyi EDOKPOLOR, Robinson Osarumwense OWENVBIUGIE. Technical and vocational education and training skills: An antidote for job creation and sustainable development of Nigerian economy

OF EDUCATION

IN THE $21^{\text {st }}$ CENTURY Vol. 75, No. 6, 2017

544

Table 3. t-test analysis between TVET lecturers in Edo and Delta States on the extent to which TVET can equip students with skills for job creation.

\begin{tabular}{|c|c|c|c|c|c|c|c|c|}
\hline Variable & Categories & $\mathbf{N}$ & $\bar{x}$ & SD & $d f$ & $t$ & $p$ & Decision \\
\hline $\begin{array}{l}\text { Extent to which TVET can } \\
\text { equip students with skills for job } \\
\text { creation }\end{array}$ & Edo & 84 & 3.57 & .21 & 296 & .153 & .127 & NR \\
\hline & Delta & 214 & 3.50 & .39 & & & & \\
\hline
\end{tabular}

Results presented in table 3 show that the aggregate mean ratings of responses by TVET lecturers in Edo and Delta States on the extent to which TVET can equip recipients with skills for job creation are 3.57 and 3.50, while the corresponding standard deviation values are .21 and .39 respectively. The table has indicated that the t-value is .153 at $\mathrm{df}$ of 296 , while the pvalue is .127. Testing at alpha level of 0.05 , the p-value is not significant, since the p-value is greater than the alpha value (0.05). Therefore, the null hypothesis is not rejected; hence there is no significant difference between the mean responses of TVET lecturers in Edo and Delta States on the extent to which TVET can equip students with skills for job creation.

Hypothesis 2: $\quad$ There is no significant difference between the mean ratings of male and female TVET lecturers on the extent to which TVET can equip students with skills for sustainable development of Nigerian economy.

Table 4. t-test analysis between male and female TVET lecturers on the extent to which TVET can equip students with skills for sustainable development of Nigerian economy.

\begin{tabular}{lcccccccc}
\hline Variable & Categories & $\mathbf{N}$ & $\overline{\boldsymbol{x}}$ & $\mathrm{SD}$ & $\mathrm{df}$ & $\mathrm{t}$ & $\mathrm{p}$ & Decision \\
\hline $\begin{array}{l}\text { Extent to which TVET can equip } \\
\text { students with skills for sustainable } \\
\text { development }\end{array}$ & Male & 156 & 3.40 & .49 & 296 & .457 & .001 & $\mathrm{R}$ \\
\hline & Female & 142 & 3.55 & .22 & & & & \\
\hline
\end{tabular}

Source: Field Study (2016). $\quad$ R: Rejected (Rejected Hypothesis).

Results presented in Table 4 show that the aggregate mean ratings of responses by male and female TVET lecturers on the extent to which TVET can equip students with skills for sustainable development of Nigerian economy are 3.40 and 3.55, while the corresponding standard deviation values are .49 and .22 respectively. The Table indicated that the t-value is .457 at $\mathrm{df}$ of 296, while the p-value is .001. Testing at alpha level of 0.05 , the p-value is significant, since the $\mathrm{p}$-value is not greater than the alpha value $(0.05)$. Therefore, the null hypothesis is rejected; hence, there is significant difference between the mean responses of male and female TVET lecturers on the extent to which TVET can equip students with skills for sustainable development of Nigerian economy.

\section{Discussion}

From the results, it is clear that TVET to a high extent can equip students with relevant skills in home economics, office, agricultural science and industrial technical for the world of work and sustainable economic growth and development. Specifically, the results from research 
question one which seeks to assess the extent to which TVET programmes can equip students with skills for job creation reveals that TVET can equip students with the requisite skills for job creation. However, this finding is in line with the assertion of Gu, Gomes and Brizuela (2011) who noted that TVET is a special type of education and training that emphasizes the application of skills and competencies required for employment in a particular occupation or cluster of related occupations in any field of social and economic activity. This also implies that TVET is an integral part of secondary and post-secondary education that is designed to educate people about, through and for careers both in work and in learning (Rojewski., Asunda, \& Kim, 2008). Hailu (2012) further asserted that after or having acquired the necessary skills, TVET graduates' career options are either wage employment or self-employment, in which both are vital that the former is to supply the industry with the skilled labour and the latter is job creation. Typically, the major aim of TVET is understood as both serving society by ensuring an educated workforce as well as improving social and economic well-being of individuals (Adams \& Gamage, 2008).

The results from research question two revealed that TVET to a very high extent can equip students with the skills to develop Nigerian economy in a sustainable manner. This further makes it clear that if people, especially the young youths, are equipped with TVET skills with which they can access the labour markets, then the incidence of underemployment, poverty, unemployment, insecurity, militancy, and other consequences of social burdens and economic exclusion would be reduced to the barest minimum in Nigeria (Famiwole, Oke \& Amadii, 2012). The finding is also in agreement with the assertion of MacLean and David (2009) who remarked that TVET is concerned with the acquisition of knowledge and skills to increase opportunities for productive empowerment and sustainable economic development in knowledge economies and rapidly changing work environment. Similarly, MacLean and Wilson (2009) describe TVET as the acquirement of skillfulness for the world of work in order to raise prospects for productive work and personal empowerment and socio-economic development for sustainable livelihoods in the speedily changing work milieu. It is on this note that Akerele (2007) and Rufai (2013) opined that TVET is an aspect of education that exposes students for the acquisition of demonstrable skills that could further be transferred into the economic benefit as well as sustainable livelihood.

\section{Conclusions and Recommendations}

The findings of this research attempted to provide a descriptive data on the important role of TVET in equipping students with requisite skills for job creation and sustainable development of Nigerian economy. However, the research specifically revealed that TVET has an important role to play in equipping students with the skills for job creation. It also showed that TVET to a very high extent can equip students with sellable skills for sustainable development of Nigerian economy. There was no significant difference between the mean responses of TVET lecturers in Edo and Delta States on the extent to which TVET can equip students with requisite skills for job creation. The research also shows a significant difference between the mean responses of male and female TVET lecturers on the extent to which TVET programme can equip students with the requisite skills for sustainable development of Nigerian economy. The researcher therefore concluded that the state of Nigeria economy, particularly in terms of unemployment, underemployment, poverty and insecurity, can only be surmounted through effective implementation of TVET programme.

Based on the findings of the research, the following recommendations were made:

1. Stakeholders of TVET should endeavour to optimize sufficient amount of resources (both financially and otherwise) in order to meet the needs of students and the society. 
James Edomwonyi EDOKPOLOR, Robinson Osarumwense OWENVBIUGIE. Technical and vocational education and training skills: An antidote for job creation and sustainable development of Nigerian economy

\section{PROBLEMS \\ OF EDUCATION \\ IN THE $21^{\text {st }}$ CENTURY Vol. 75, No. 6, 2017 \\ 546}

2. Regular supply of the state-of-the-art facilities should be collaboratively embarked on by governments and other major stakeholders so as to ensure the effective delivery of TVET programmes in Nigeria.

3. Government should endeavour to provide adequate funds in order for TVET managers to be able to source for qualified manpower that would effectively teach TVET courses.

4. Government should endeavour to implement an advocacy programme in order for the people of Nigeria to be aware of the relevance of TVET on job creation and sustainable development of Nigerian economy.

\section{References}

Adams, D., \& Gamage, D. T. (2008). A study of leadership effectiveness in a large VET institution in Australia. International Journal of Educational Management, 22 (3), 214-228.

Adekoya, C. O. (2010). An imperativeness of adoption: A human right approach to poverty reduction strategy in Nigeria. University of Ado-Ekiti Law Journal, 4, 36-71.

Adeyemi, A. B., \& Titiloye, K. A. (2014). Effective management of small scale enterprises in Nigeria. Kaduna State. Print Mark Press and Bindery.

Adewuyi, J. O., \& Okemakinde, T. (2013). Higher education financing in Nigeria: Issues and trends. International Journal of Educational Administration and Policy Studies, 5 (7), 121-127.

Agrawal, T. (2013). Vocational education and training programmes (VET): An Asian perspective. AsiaPacific Journal of Cooperation Education, 14 (1), 16-17.

Akerele, W. O. (2007). Management of technical and vocational education in Nigeria: The challenges of the country. Lagos Journal of Educational Administration and Planning, 3 (1).

Ary, D., Jacobs, L. C., Sorensen, C. K., \& Walker, D. A. (2014). Introduction to research in education (9 $9^{\text {th }}$ Ed.). United States: Wadsworth, Cengage Learning.

Asian Development Bank (ADB) (2004). Improving technical education and vocational training: Strategies for Asia. Manila, Philippines: Asian Development Bank.

Asian Development Bank (ADB) (2008). Education and skills: Strategies for accelerated development in Asia and Pacific. Manila Philippines: Department of External Relations.

Awotunde, D. O. (2000). Technical and vocational education for national development: The Nigeria experiences. A Lead Paper Presented at the National conference, University of Ibadan, on Science $13^{\text {th }}$ August, 2000, Ibadan.

Badawi, A. A. (2013). TVET and entrepreneurship skills. In Revisiting global trends in TVET: Reflections on theory and practice. UNESCO International Centre for Technical and Vocational Education and Training (UNEVOC). Retrieved from http://www.unevoc.unesco.org/fileadmin/up/2013 epub_revisiting global trends in tvet_book.pdf.

Bryman, A. (2007). Qualitative data analysis. London, UK: SAGE Publications.

Burchardt, T., Le Grand, J., \& Piachaud, D. (2002). Introduction. In J. Hills., J. Le Grand., \& D. Piachaud (Eds.). Understanding social exclusion. Oxford University Press, Oxford.

Chukwumerije, U. (2011). The imperative of technical and vocation education in Nigeria. Convocation Lecture, Anambra State University. December 7, 2011.

Department for International Development (DFID) (2007). Educating out of poverty. Edinburgh: DfID.

Edwards, J. (2008). Building a self-sustaining, indigenous film industry in Kenya. Retrieved from http:// worldstoryorganization.org/docs/WSOKenyaFilmIndustryReport.pdf

Ekpenyong, L. E., \& Edokpolor, E. J. (2015a). Winning the war against unemployment and poverty in Nigeria: is there a role for TVET-private sector partnership? The Nigerian Vocational Association Journal (NVAJ), 20 (1), 125 - 132

Ekpo, A. H. (2011). Nigeria and its growing unemployment crisis. Broad Street Journal. Nigeria. TELL Magazine, 7, 28.

European Training Foundation (ETF) (2006a). Skills development for poverty reduction. Luxembourg, European Union Publications Office. 
James Edomwonyi EDOKPOLOR, Robinson Osarumwense OWENVBIUGIE. Technical and vocational education and training skills: An antidote for job creation and sustainable development of Nigerian economy

Famiwole, R. O., Oke, J. O., \& Amadii, N. S. (2012). Potentials of vocational technical education: Empowering youths and vulnerable adults for poverty reduction in Nigeria. International Journal of Social and Management, 1 (2).

Federal Republic of Nigeria (FRN) (2004). National policy on education, Lagos: NERDC Press.

Global e-Schools and Communities Initiative (2013). Development of 21st century skills for innovation and enterprise: Exploring the role of Informal learning environments in the development of skills and aptitudes for the digital creative media industries. Retrieved from http://gesci.org/ fileadmin/user_upload/2_Youth_Skills_Enterprise_Files/AKE_research_-_21C_Skills_Full_Report___2012_.pdf

Gu, C. C., Gomes, T., \& Brizuela, V. S. (2011). Technical and vocational education and training in support of strategic sustainable development. Thesis submitted for completion of Master of Strategic Leadership towards Sustainability, Blekinge Institute of Technology, Karlskrona, Sweden.

Hailu, E. T. (2012). Analyzing the labour outcomes of TVET in Ethiopia: Implication of challenges and opportunities in productive self-employment of TVET graduates. Being a Research Paper Presented in Partial Fulfillment of the Requirements for Obtaining the Degree of Masters of Arts in Development Studies.

Hardi, P. A. (1997). Assessing sustainable development: Principles in practice. Manitoba: International Institute for Sustainable Development.

Igbinedion, V. I., Edokpolor, J. E., \& Oyenuga, A. O. (2015). Trends towards a closer integration of vocational education and career guidance in Nigeria. The Vocational and Applied Science Journal (TVASJ), 12, 48-63.

Igwe, L. E. B., \& Oragwu, A. A. (2014). Techno-vocational skills acquisition and poverty reduction strategies in vocational institutions: The case of rivers state. African Journal of Education and Technology, 4 (1), 47-58.

International Labour Organization (ILO) (2008). Skills for improving productivity, employment growth and development. Geneva. International Labour Office.

Jack, K. N., \& Jelly, K. T. (2005). Research methods in physical activities. Chicago: Human Kinetics Campaign Report, 62-81.

Kingombe, C. (2012). Lessons for developing countries from experience with technical and vocational education and training. In O. E. G. Johnson (Ed). Economic challenges and policy issues in early twenty-first-century Sierra Leone. International Growth Centre Retrieved from https://www. theigc.org/wp-content/uploads/2012/03/Johnson-Ed.-2012-.pdf.

Kurya, U. L., \& Hassan, B. (2007). Technical and vocational education for productive and sustainable development in Nigeria. Proceedings of the $20^{\text {th }}$ Annual Conference of the Nigeria Association of Teachers of Technology (NATT). Kaduna, Nigeria.

Ladipo, M. K., Akhuemonkhan, I. A., \& Raimi, L. (2013) Technical vocational education and training (TVET) as mechanism for sustainable development in Nigeria (SD): Potentials, challenges and policy prescriptions. Being a paper Presented at the Commonwealth Association of Technical Universities and Polytechnics in Africa (CAPA) International Conference, Held in Banjul, Gambia between 3-8 June 2013. Banjul.

Li, Q., Swaminathan, H., \& Tang, J. (2009). Development of a classification system for engineering student characteristics affecting college enrollment and retention. Journal of Engineering Education, 98 (4), 361-376.

Lisbon Council (2007). Skills for the future. A paper prepared for the European Union's Lisbon Council. Retrieved from www.lisboncouncil.net/component/downloads/?id=214.

Maclean, P. (2008). Education for peace building and sustainable development: Delusion, illusion, or reality? Retrieved from http://www.winderdoon.com/WEFT/files/publication_rupertmaclean_educationforpeace.pdf

McLean, R., \& David, N. W. (2009). International handbook of education for the changing world of work: Bridging academic and vocational learning. Retrieved from http://toolkit.ineesite.org/toolkit/INEEcms/uploads/1093/International_Handbook_of_Education_Changing.pdf.

McLean, R., \& Wilson, D. (Eds.) (2009). International handbook of education for the changing world of work: Bridging academic and vocational learning, 1 (6). Springer Science + Business Media B. V. 2009.

\section{PROBLEMS \\ OF EDUCATION \\ IN THE $21^{\text {st }}$ CENTURY \\ Vol. 75, No. 6, 2017}


James Edomwonyi EDOKPOLOR, Robinson Osarumwense OWENVBIUGIE. Technical and vocational education and training skills: An antidote for job creation and sustainable development of Nigerian economy

\author{
PROBLEMS \\ OF EDUCATION \\ IN THE $21^{\text {st }}$ CENTURY \\ Vol. 75, No. 6, 2017 \\ 548 National Association of State Directors of Career and Technical Education Consortium (NASDCTEC) \\ (2003). Back to school: Career Tech 101. Retrieved from http://www.careertech.org/show/publi- \\ cations.
}

National Bureau of Statistics (NBS) (2016). Unemployment/under-employment watch. Abuja. Retrieved from http/nigerianstat.gov.ng/download/397.pdf.

Netherlands Organization for International Cooperation in Higher Education (2010). NICHE strategy on technical and vocational education and training (TVET). Retrieved from https://www.nuffic.nl/ en/files/documents/niche-strategy-on-technical-and-vocational-education-and-training-tvet.pdf.

Olaitan, S. O. (1996). Vocational and technical education in Nigeria: Issues and analysis. Onitsha: Noble Graphic Press.

Olajide, S. E. (2015). Repositioning technical and vocational education toward eradicating unemployment in Nigeria. International Journal of Vocational and Technical Education, 7 (6), 54-63. Retrieved from http://www.academicjournals.org/article/article1436978905_Olajide.pdf.

Organization for Economic Co-operation and Development (OECD) (2009). Learning for jobs: OECD policy review of vocational education and training initial report. Paris, OECD.

Organization for Economic Co-operation and Development (OECD) (2009). 21st century skills and competences for new millennium learners in OECD Countries. Retrieved from http://www.oecd.org/ officialdocuments/publicdisplaydocumentpdf/?cote=EDU/WKP(2009)20\&doclanguage=en.

Osinubi T. S. (2005). Macro econometric analysis of growth, unemployment and poverty in Nigeria. Pakistan Economic and Social Review, 48 (2), 249-269. Retrieved from http://pu.edu.pk/images/ journal/pesr/PDF-FILES/7\%20OSINUBI\%20Macroeconometric\%20Analysis\%20of\%20Nigeria.pdf.

Prospects (2010). Graphic design: Your skills. Retrieved from http://www.prospects.ac.uk/options graphic_design your_skills.htm.

Rojewski, J. W., Asunda, P., \& Kim, S. J. (2008).Trends in career and technical education research. Journal of Career and Technical Education, 24 (2), 57-68. Retrieved fromhttp://files.eric.ed.gov/ fulltext/EJ860502.pdf.

Rufai, A. (2013). Human capital development in technical and vocational education and training (TVET) for sustainable national development. Journal of Education and Practice, 4 (7), 100-107.

Sen, A. (1999). Development as freedom. New York: Knopt.

Tilak, J. B. G. (2002). Vocational education and training in Asia. In J. P. Keeves \& R. Watanabe (ed.). The hand book on educational research in the Asia Pacific Region. Berlin, Germany: Kluwer.

United Nations Educational, Scientific and Cultural Organization (UNESCO) (2005). Revised recommendation concerning technical and vocational education (2001): In UNESCO (2005). Normative instruments concerning technical and vocational education. 7. Retrieved from http:/unesdoc. unesco.org/images/0014/001406/140603e.pdf.

United Nations Educational, Scientific and Cultural Organization (UNESCO). (2010). Education for sustainable development (ESD). Retrieved from http://www.unesco.org/en/esd/.

UNESCO-UNEVOC (2009). TVET and ESD. Retrieved from http://www.unevoc.unesco.org/ wiki.0.html?\&no_cache $=1 \&$ tx_drwiki_pi1[keyword] $=$ more_about_tvet_for_sd.

UNESCO-UNEVOC (2012) Transforming TVET from idea to action. UNESCO-UNEVOC International Centre for Technical and Vocational Education and Training, UN Campus, Bonn, Germany.

World Bank (2007).World development report. Washington, DC, World Bank.

World Commission on Environment and Development (WCED) (1987). Our common future. Oxford: Oxford University Press.

Worldometers (2017). Population of Nigeria. Retrieved from http://www.worldometers.info/world-population/nigeria-population. 
James Edomwonyi EDOKPOLOR, Robinson Osarumwense OWENVBIUGIE. Technical and vocational education and training skills: An antidote for job creation and sustainable development of Nigerian economy

ROBLEMS

OF EDUCATION

IN THE $21^{\text {st }}$ CENTURY

Received: October 15, 2017

Accepted: December 08, 2017

75, No. 6, 2017

549

James Edomwonyi Edokpolor

M.ed, Assistant Lecturer, Department of Social Science Education, Faculty of Arts and Education, Benson Idahosa University, P.M.B.1100, Benin City, Edo State, Nigeria.

E-mail: jedokpolor@biu.edu.ng

Robinson Osarumwense Owenvbiugie
PhD, Lecturer One, Business Education Unit, Department of Vocational and Technical Education, Faculty of Education, University of Benin, P.O. Box 1154, Benin City, Edo State, Nigeria.

E-mail: Osarumwense.owenvbiugie@uniben.edu 